\title{
PETR A. STOLYPIN AND THE RUSSIAN NOBILITY
}

\author{
Petr S. Kabytov \\ Samara National Research University, Samara, Russian Federation \\ Ekaterina P. Barinova \\ Samara State Economic University, Samara, Russian Federation
}

\begin{abstract}
Introduction. The article examines the attitude of the Russian nobility to the reformatory activity of Chairman of the Council of the Ministers of the Russian Empire P.A. Stolypin. The authors focus on the analysis of the attitude of the conservative wing of the noble elite represented in the State Duma, the State Council, the Council of the United Nobility, the Council for Local Economy under the Ministry of Internal Affairs to the government policy. Methods. In the historiography of the problem three periods are highlighted. It was found that up to $90 \mathrm{~s}$ of the $20^{\text {th }}$ century negative evaluation of the personality and activity of P.A. Stolypin remained in the scientific literature. Only in the modern period of the Russian historiography development many mythologems were criticized and there appeared scientific works that overcame many stereotypes and dogmatic representations about the last Russian reformer's life and activity on the basis of the complex of documentary sources. Analysis. The regional nobility sharply criticized the new government agricultural policy, despite the fact that a large part of landowners and nobles reacted positively to implementing Stolypin's agrarian reform. Stolypin's program of updating Russia was ambiguously perceived by the elite of the Russian nobility. Such bills as "On the Extension of the Regulation on Zemsky Institutions to Vitebsk, Volyn, Kiev, Minsk, Mogilev and Podolsk Provinces", "On Amending and Supplementing the Existing Laws on Uezd Establishments in the Provinces", "On Establishing the Main Principles for Organizing Provincial Institutions" were met with hostility and regarded as an encroachment on traditional privileges of the noble class. Other bills of Stolypin did not find much support among the nobility as well. His fall began immediately after the appeasement of the country. Results. His legislative activity, the desire to accelerate the process of Russia's renewal irritated not only the conservative wing of the noble elite, but also Emperor Nicholas II. The tragedy of the last imperial reformer P.A. Stolpin was that he had no social support either among the ruling elite and the nobility, or in society, that eventually led to his isolation and tragic death. nobility.

Key words: P.A. Stolypin, Nicholas II, Russian nobility, State Duma, State Council, Council of the United

Citation. Kabytov P.S., Barinova E.P. Petr A. Stolypin and the Russian Nobility. Vestnik Volgogradskogo gosudarstvennogo universiteta. Seriya 4. Istoriya. Regionovedenie. Mezhdunarodnye otnosheniya [Science Journal of Volgograd State University. History. Area Studies. International Relations], 2019, vol. 24, no. 3, pp. 79-91. (in Russian). DOI: https://doi.org/10.15688/jvolsu4.2019.3.7
\end{abstract}

\section{ПЕТР АРКАДЬЕВИЧ СТОЛЫПИН И РОССИЙСКОЕ ДВОРЯНСТВО}

\author{
Петр Серафимович Кабытов \\ Самарский национальный исследовательский университет им. акад. С.П. Королева, \\ г. Самара, Российская Федерация
}

\section{Екатерина Петровна Баринова}

Самарский государственный экономический университет, г. Самара, Российская Федерация 
Аннотация. В статье исследуется отношение российского дворянства к реформаторской деятельности Председателя Совета министров Российской империи П.А. Столыпина. В историографии проблемы выделены три периода, установлено, что вплоть до 90-х гг. ХХ в. в научной литературе сохранялись негативные оценки личности и деятельности П.А. Столыпина. Лишь в новейший период многие мифологемы были подвергнуты критике и появились научные труды, в которых на основе комплекса документальных источников были преодолены стереотипы и догматические представления о жизни и деятельности последнего российского реформатора. В центре внимания авторов статьи анализ отношения консервативного крыла дворянской элиты, представленной в Государственной думе, Государственном совете, Совете по делам местного хозяйства при Министерстве внутренних дел и Совете объединенного дворянства, к правительственной политике. Именно эта часть дворянства выступала с резкой критикой новой правительственной политики, несмотря на то что большая часть помещиков позитивно отнеслась к реализации столыпинской аграрной реформы. Неоднозначно была воспринята элитой российского дворянства столыпинская программа обновления России, в том числе такие законопроекты, как «О распространении действия Положения о земских учреждениях на Витебскую, Волынскую, Киевскую, Минскую, Могилевскую и Подольскую губернии», «Об изменении и дополнении действующих узаконений об уездных установлениях в губерниях», «Об установлении главных начал устройства губернских учреждений», которые были встречены враждебно и расценены как посягательство на традиционные привилегии благородного сословия. Не находили поддержки у дворянства и другие законопроекты Столыпина. Его падение началось сразу после умиротворения страны. Законотворческая активность и стремление ускорить процесс обновления России вызывали раздражение не только у консервативного крыла дворянской элиты, но и у императора Николая II. Вклад авторов: П.С. Кабытов - систематизация и представление авторского аналитического материала о реформаторской деятельности П.А. Столыпина; Е.П. Баринова - постановка проблем о взаимоотношениях членов Совета объединенного дворянства к реформам П.А. Столыпина.

Ключевые слова: П.А. Столыпин, Николай II, российское дворянство, Государственная дума, Государственный совет, Совет объединенного дворянства.

Цитирование. Кабытов П. С., Баринова Е. П. Петр Аркадьевич Столыпин и российское дворянство // Вестник Волгоградского государственного университета. Серия 4, История. Регионоведение. Международные отношения. - 2019. - Т. 24, № 3. - С. 79-91. -DOI: https://doi.org/10.15688/jvolsu4.2019.3.7

Введение. В современных условиях резко возрос интерес к анализу истории Российской империи конца XIX - начала XX века. Многие процессы, происходящие в России, обусловлены поиском путей выхода из кризисной экономической ситуации. В этой связи особое значение приобретает вопрос соотношения реформаторских и революционных преобразований в стране. Обращение исследователей к данной проблематике позволяет историкам проанализировать опыт российских реформ, выявить пути и проблемы адаптации к ним различных социальных слоев населения.

На протяжении десятилетий жизнь и деятельность П.А. Столыпина фальсифицировалась в угоду господствовавшей в советскую эпоху марксистско-ленинской доктрине. Последний российский реформатор однозначно оценивался в научных исследованиях как охранитель самодержавного строя, консерватор, а время проведения столыпинских реформ маркировалось в школьных и вузовских учебниках как период реакции. Преобладали отрицательные оценки политики П.А. Столыпи- на, которая была направлена на поиск равнодействующей, способной перевести страну из состояния революционного хаоса на путь реформирования экономики и государственного строя. И хотя к юбилеям П.А. Столыпина было опубликовано большое число работ, многие аспекты его жизни и деятельности все еще остаются недостаточно изученными.

П.А. Столыпин был призван в правительство императором Николаем II в 1906 г., когда страна находилась еще в условиях революционного хаоса. В этой связи ему предстояло решать ряд глобальных задач, связанных с умиротворением революционного движения. Одновременно он должен был предложить российскому обществу программу системных реформ. Выход из кризиса он видел в проведении аграрной реформы, в ходе которой в России должен был увеличиться слой земельных собственников из числа крестьян-хуторян и отрубников. По его мнению, укрепление общинной земли за счет передачи в частную собственность объективно способствовало резкому сокращению социальных катаклизмов 
в стране и установлению стабильности в обществе. Программа Столыпина предусматривала реформирование структуры органов власти. Вместе с тем в его концепции сохранялись традиционные подходы, связанные с необходимостью сохранения устоев государственного строя. Немало усилий Столыпин приложил для того, чтобы создать систему взаимодействия между императорской властью и первым российским парламентом Государственной думой и Государственным советом, что создавало условия для реализации реформ в стране. П.А. Столыпин не был сторонником революционных изменений, которые неизбежно порождали хаос в стране и ввергали народ в очередную смуту. Во многом эти пути разрешения проблем схожи с современными представлениями российских политиков.

В статье ставится цель показать отношение представителей высших слоев российского дворянства к реформаторской деятельности Председателя Совета министров Российской империи Петра Аркадьевича Столыпина, который считал, что создание слоя земельных собственников из числа землеустроенных крестьян придаст импульс ускорению модернизационных процессов в аграрном секторе страны и сократит социальную напряженность в российском обществе. Впервые показана эволюция взглядов представителей губернских корпоративных организаций по отношению к реформаторской деятельности П.А. Столыпина, квинтэссенцией которых стали выступления региональных делегатов на съездах объединенного дворянства.

Методы. Вокруг имени П.А. Столыпина возникло немало мифов и спекуляций, которые заполнили как публицистику, так и научные труды. До сих пор в исторической литературе можно встретить самые разноречивые суждения - от крайне резкой критики до неумеренных похвал. Первый этап изучения рассматриваемой проблемы характеризуется тем, что в дореволюционный период на взгляды современников П.А. Столыпина повлияли такие факторы, как незавершенность исторического процесса, своеобразная эйфория от первых побед и поражений в дни первой русской революции и работы I и II Государственной думы. В работах П.П. Маслова, Н.Н. Су- ханова, В.М. Чернова в силу определенной политической заданности есть налет тенденциозности. Критикуя правительственный курс, они акцентировали внимание на тех официальных данных, которые позволяли усиливать их аргументы [17; 29; 31]. Подобные подходы к аграрному строю России и аграрной политике правительства можно встретить в публицистических сочинениях и монографиях народников, энесов, кадетов [13; 24]. Лидер российских большевиков В.И. Ленин считал, что столыпинское земельное законодательство есть не что иное, как решение новых задач старыми методами [16]. Его оценки стали методологической основой для всех советских историков, изучавших историю России начала $\mathrm{XX}$ века.

Второй этап историографии исследуемой проблемы охватывает период с момента установления советской власти до середины 80 -х гг. ХХ столетия. В советской историографии имя Столыпина стало нарицательным. Ленинская характеристика Столыпина как «уполномоченного российского дворянства», широко используемая в советской историографии, трактовалась как полная солидарность Столыпина и объединенного дворянства. О взаимоотношениях П.А. Столыпина с дворянством и воздействии Совета объединенного дворянства на его законотворческую деятельность в условиях функционирования думской системы рассуждали в своих работах В.С. Дякин и Ю.Б. Соловьев, пытаясь ответить на вопрос: был ли шанс у Столыпина в реформировании России [7; 8; 28]. Обстоятельный анализ взаимоотношений П.А. Столыпина с российским парламентом содержится в монографии А.Я. Авреха, для которого Столыпин прежде всего правый, крайний реакционер, проводник политики аграрного и политического бонапартизма [2].

В новейший период развития отечественной науки (вторая половина 1980-х гг. - настоящее время) историографическая ситуация существенно изменилась. Произошел резкий всплеск все возрастающего интереса к личности и деятельности П.А. Столыпина. В научной литературе наметилось стремление к отказу от многих мифологем и отрицательных оценок по отношению к деятельности последнего российского реформатора. Отход от 
марксистско-ленинской методологии позволил по-новому подойти к анализу таких проблем, как функционирование земельного рынка [30], финансирование сельского хозяйства в период проведения столыпинской земельной реформы [7], история поместного дворянства [4]. В 1990-2000-е гг. резко возросло число публикаций, в которых освещались различные аспекты жизни и деятельности П.А. Столыпина [1; $9 ; 10 ; 11]$. В последней книге А.М. Анфимова Столыпин показан как реформатор. Он попытался проследить воздействие столыпинской земельной реформы на эволюцию аграрного строя России [3]. И.В. Островский полагает, что внутренний политический курс Столыпина был направлен на создание «своеобразного буфера между крайними политическими группировками» [21]. В.В. Казарезов считает, что советские историки намеренно исказили мысли, проекты и дела П.А. Столыпина, его образ как человека и государственного деятеля [12]. В статье А.П. Бородина был поставлен вопрос о взаимоотношениях П.А. Столыпина с Советом объединенного дворянства [5].

В монографии С. Ольденбурга говорится о Манифесте 3 июня 1907 г., который, по мнению автора, имел «еще большее принципиальное значение, чем избирательный закон», завершивший перестройку государственной власти. С. Ольденбург писал о роли П.А. Столыпина в умиротворении России, его взаимодействии с Думой и Николаем II. Особый интерес представляет трактовка историком правительственного кризиса, вызванного стремлением Столыпина ввести земские учреждения в западных губерниях. Он акцентирует внимание на падении престижа Столыпина в российском обществе [23].

Зарубежная историография представлена научными трудами английских, французских, итальянских, американских, японских исследователей. Как правило, они уделяют основное внимание государственной деятельности П.А. Столыпина и реализации его либеральных реформ. К. Мацузато полагает, что столыпинскую аграрную реформу необходимо рассматривать прежде всего как агротехнологическую революцию в деревне [18]. По замечанию ряда американских историков $[15 ; 19$; 35], осуществление реформ «было самым важным политическим шагом царского правитель- ства между 1861 и 1917 гг.», а П.А. Столыпин символизировал «объединение правительства с обществом» $[19$, с. 5]. В отличие от советских историков, Д. Мейси иначе оценивает мотивы разработки и реализации реформ. По его мнению, ими «можно обозначить период, когда правительство лишается доверия и политический режим рушится из-за внутреннего разлада» $[19$, с. 5,12$]$. Высокую оценку деятельности П.А. Столыпина дает в своих исследованиях А. Ашер, который подчеркивает, что Столыпин преуспел в возрождении правительственной власти в 1906-1907 гг., проведении аграрной реформы, «самой далеко идущей реформы в России со времен отмены крепостного права в 1861 г.» [34].

Государственная деятельность П.А. Столыпина нашла отражение в монографиях английского историка Т. Шанина, полагающего, что Столыпин «не был изобретателем ключевых моментов тех реформ, которые связаны с его именем», а «связал эти элементы воедино и обосновал их опытом революции, подкрепил их авторитетом человека...», выступил в роли последнего рыцаря самодержавной монархии. Т. Шанин говорит о программе реформ как столыпинском генеральном плане, называет его вторым Бисмарком, подчеркивает несгибаемый монархизм Столыпина [32, c. 367-369].

Живучесть традиционных представлений вызвана, с одной стороны, тем, что в течение длительного периода в советской историографии транслировались оценки, содержащиеся в работах В.И. Ленина. С другой стороны, сказывались политические пристрастия исследователей, а также инерционная сила традиции, которая оказывает воздействие на историков.

Настоящая статья написана на основе историко-аксиологического анализа комплекса документальных публикаций, в которых в полной мере нашли отражение многие аспекты взаимоотношений П.А. Столыпина и дворянства. Использование ценностного подхода позволило показать степень влияния на концепцию реформ П.А.Столыпина революционных событий 1905-1907 гг. и их оценку различными социальными слоями.

Сравнительно-сопоставительный анализ материалов съездов уполномоченных дворян- 
ских губернских обществ позволил выявить отношение поместного дворянства к проводимым реформам. Позиция участников съездов в концентрированном виде отражала настроения регионального поместного дворянства. Ценная историческая информация содержится в воспоминаниях участников событий, анализ которых позволяет выявить сложную гамму чувств и эмоций дворян к реформаторским новеллам П.А.Столыпина. Предпринято новое прочтение уже известных источников, так как в советский период многие историки в силу ряда объективных факторов вольно или невольно страдали профессиональной «слепотой», что и обусловило сохранению в их нарративах многих мифологем.

Анализ. После создания третьеиюньской системы начинается 4-летнее падение престижа Столыпина. Хотя он по инерции еще пользовался доверием царя и претворял в жизнь свою программу, постепенно Николай II решил, что активный глава правительства выдвигается на первый план, чрезмерно затеняя его фигуру. Рейтинг премьер-министра П.А. Столыпина стал снижаться как среди окружения Николая II, так и в правительственной среде. Негативно относились к Столыпину и в Государственном совете, где правые (Дурново, Трепов, Витте) открыто выступали против столыпинских реформ. В Совете министров также не было единства. Падала поддержка реформ правительства в среде поместного дворянства, не готового поступаться своими правами и привилегиями. Менялись расстановка политических сил и настроения депутатов III Государственной думы, с которой поначалу у премьера установились взаимопонимание и сотрудничество. Если в 1907-1909 гг. по свидетельству С.С. Ольденбурга «между П.А. Столыпиным и думским большинством установилось дружеское взаимодействие» [23, с. 442], его поддерживала партия октябристов, то затем она переходит в оппозицию к его начинаниям. Эта поддержка оказалась неровной, условной, «иногда радовала дружностью и кратковременностью, иногда оказывалось и не поддержка вовсе, а состязание и даже столкновение» [27, с. 135]. Партия националистов, «во всяком случае, поддерживавшая его и пользовавшаяся и от него разными преимуществами» была откровенно слабой и пло- хо организованной. Не прерывались конфликты Столыпина с партией правых, лидеры которой «пользовались всяким случаем, чтобы очернить Столыпина в глазах монарха», упрекали его в союзе с октябристами. Современники отмечали, что в параллель представителям левых партий, осуждавших политику Столыпина, «правые мешали и грозили ему неисполнимыми требованиями» [6, с. 602-603].

Реализация программы реформ П.А. Столыпина могла быть успешной лишь при условии соблюдения принципа «порядок и реформы», который предусматривал переход от митинговых настроений I и II Государственной думы к законотворческой деятельности III Государственной думы, что на практике означало установление паритетных отношений имперской власти с парламентом. В начале 1907 г. П.А. Столыпин так излагал свое политическое кредо: «Реформы во время революции необходимы, так как революцию породили в большей степени недостатки внутреннего уклада. Если заняться исключительно борьбой с революцией, то в лучшем случае устраним последствие, а не причину: залечим язву, но порожденная кровь породит новые изъязвления. К тому же путь реформ торжественно возвещен, создана Государственная дума и идти назад нельзя» [7, с. 114]. Однако впоследствии по мере затихания революционных настроений в обществе Столыпин постепенно отклонялся от курса реформирования и возвратился к старым приемам управления.

Реализация новой аграрной политики обусловливала ломку традиционного образа жизни российской деревни. Суть новой аграрной политики правительства была сформулирована П.А. Столыпиным в Государственной думе в ноябре 1907 г.: «Необходима не беспорядочная раздача земель, не успокоение бунта подачками - бунт погашается силой, а признание неприкосновенности частной собственности и, как последствие, отсюда вытекающее, создание мелкой личной собственности, реальное право выхода из общины». К обсуждению аграрного законопроекта указа 9 ноября 1906 г. Государственная дума приступила 23 октября 1908 года. Правительство рассчитывало, что политика разрушения общины и выделения крестьянина-собственника за это время станет необратимой, пустит глубокие 
корни в деревне. Столыпин, выступая в Думе при обсуждении этого указа, отмечал, что «правительство ставило ставку не на убогих и пьяных, а на крепких и сильных». «Крепкий личный собственник, - обосновывал он свое мнение, - нужен для переустройства нашего царства, переустройства на крепких монархических устоях» $[26$, с. 45-46, 75]. А.Я. Аврех отмечал ожесточенную полемику в Государственной думе по этому вопросу, полагая, что «в основе кадетской критики указа лежал страх перед революцией» $[1$, с. 74]. Правые депутаты-монархисты, напротив, поддерживали «введение класса собственников». В разгар революционных событий дворяне поддержали правительственную аграрную политику, поскольку она была направлена на создание в деревне слоя крестьян-собственников, уничтожение общины и сохранение дворянского землевладения. В выступлениях делегатов на II съезде объединенного дворянства (1418 ноября 1906 г.) подчеркивалась необходимость перехода от общинного владения к подворному «с устройством хуторов на отрубных участках». Дворянство полагало, что реформа будет способствовать прекращению «аграрных беспорядков» [22, т. 1, с. 224-225, 227232]. Только отдельные представители крайне правого консервативного дворянства открыто высказались против аграрной реформы. Опасаясь убыли дворянского землевладения, они обвинили правительство в предательстве интересов поместного дворянства и создании гипотетических условий для экспроприации помещичьей собственности. Свое мнение они мотивировали предположением, что деятельность землеустроительных комиссий, возможно, будет иметь «революционный» характер. Указав в преамбуле своего выступления на связь реформы с государственными интересами и «прямой связью со средствами страны», князь Н.Ф. Касаткин-Ростовский отметил, что «из декларации правительства мы ясной программы реформ не видим» $[22$, т. 1 , c. 374]. В связи с этим он предложил создание финансового комитета из представителей правительства, земских и дворянских учреждений. На это заявление довольно резко возразил его соратник по партии Н.Е. Марков, который подчеркнул, что «дело дворян - помочь правительству, усилить его правительствен- ную власть». Большая часть участников съезда справедливо полагала, что «рациональнее принять на себя роль инициаторов» в деле проведения правительственной политики на местах $[22$, т. 1 , с. 375,455$]$.

В Государственном совете также не было единодушной поддержки реформаторской деятельности П.А. Столыпина. Споры в земельной комиссии касались не сущности, а темпов и способов проведения аграрной реформы. Часть членов Госсовета предлагали проводить реформу постепенно, путем предоставления разумных льготных и поощрительных мер для перехода крестьян-общинников к личному землепользованию.

При обсуждении доклада В.И. Гурко в феврале 1909 г. на V съезде объединенного дворянства были сделаны первые оценки претворения в жизнь столыпинской аграрной реформы. К.Ф. Головин дал в целом позитивную оценку аграрной политике правительства: «...как бы он (указ 9 ноября 1906 г. - Авт.) мало ни был удовлетворителен, но в настоящий момент он сослужил свою службу. Он остановил то крестьянское брожение, которое было основано на голоде земли...» $[22$, т. 2 , кн. 1, с. 127]. С.П. Фролов указал, что только решительные меры правительства, которое «сумело и смогло своевременно издать закон 9 ноября 1906 года» и обеспечить его практическое осуществление, способствовали дальнейшему развитию сельского хозяйства [22, т. 2 , кн. 1 , с. 128$]$. Главным недостатком закона помещики считали право крестьян на отчуждение своих участков. Они справедливо полагали, что в этом случае возможен резкий рост численности «безработного пролетариата. Анализируя исполнение закона 9 ноября 1906 г., А.Д. Кашкаров высказал мнение о том, что рядом положений закона создается путаница: «крестьянин, укрепивший полосу, считает, что он вечно ей будет пользоваться» [22, т. 2, кн. 1, с. 126]. В ряде дворянских выступлений звучало рефреном, что В.И. Гурко подрывает значение государственной власти, авторитет правительства П.А. Столыпина. Отвечая на нападки оппонентов, В.И. Гурко предложил съезду разработать меры для дальнейшего развития народного хозяйства. Он заметил, что нельзя останавливаться на достигнутом: «Я первый заявил, что нынешний со- 
став правительства имеет большие заслуги. ...Правительство нам обеспечило в стране порядок. Дало возможность жить». «Но, что же дальше? - вопрошал он. - ...Мы видим, что, с одной стороны, нам предлагают все наше дворянское сословие упразднить... с другой, в порядке экономической политики никаких мероприятий не применялось...» [22, т. 2, кн. 1, с. 144, 214$].$

Конечно, реализация аграрной реформы сдерживалась стремлением правительства сохранить дворянское землевладение. Ее ограниченный характер отмечали даже сами представители сословия: «левые партии смотрят на закон 9 ноября, как на изданный для помещиков, для того чтобы населить эти местности мелкими помещиками, которые будут защищать свои интересы с другими крупными помещиками» [22, т. 2, кн. 1, с. 525]. Тем не менее результатом аграрных преобразований стало возрастание численности земельных собственников - крестьян и прекращение разгрома дворянских имений. В протестном движении крестьян стали преобладать выступления против столыпинского землеустройства, что было обусловлено стремлением большинства крестьян сохранить сельскую общину. В ходе реализации столыпинской аграрной реформы создавалась новая инфраструктура сельского хозяйства: возникла сеть элеваторов, участковая агрономия, стали функционировать опытные станции и хозяйства, существенно расширилась деятельность Крестьянского поземельного банка, быстрыми темпами развивалось кооперативное движение.

В программу «обновления России» П.А. Столыпина органично входили реформы в области местного управления, суда, земского самоуправления. Эти либеральные буржуазные реформы по сути должны были стать органичным продолжением аграрного законодательства, расширить права земельных собственников. Законопроект «Об изменении и дополнении действующих узаконений об уездных установлениях» ограничивал права уездных предводителей дворянства. По существу резко сузилось участие сословия в управлении страной. Столыпин стремился предоставить новым землевладельцам из числа благоустроенных крестьян возможность играть большую роль в органах местного самоуправ- ления. Законопроект предусматривал, что руководителями органов местного самоуправления должны стать назначаемые правительством чиновники. Руководство земской деятельностью передавалось советам и собраниям, которые избирались местными жителями на основе всесословности.

В 1907 г. П.А. Столыпин возобновил деятельность совета по делам местного хозяйства при МВД, который современники метко окрестили преддумьем. Он полагал, что это учреждение будет обсуждать важнейшие законопроекты, предложенные правительством, перед внесением их на рассмотрение Государственной думы и Государственного совета. Самарский губернский предводитель дворянства А.Н. Наумов, участник заседаний совета, вспоминал, что «спешка и необычайное обилие намеченных коренных реформ производили впечатление чего-то хаотического, ненормального». «Бросалось в глаза, - отмечал он, - отсутствие обдуманного, систематизированного плана реформирования старого порядка» [20, кн. 2, с. 133-134]. А.Н. Наумов полагал, что реформы в области местного управления носили насильственный характер и не учитывали особенностей российской действительности. Часть членов совета высказали мнение о необходимости принципиального обсуждения реформ волостного и поселкового управления и соблюдения осторожности в их применении. П.А. Столыпин крайне негативно воспринял возражения и критику членов совета. А.Н. Наумов вспоминал, что Столыпин расценивал как личную обиду «каждое принципиальное возражение», полагая, что дворянство мешает и «ставит рогатки» в столь важном деле [20, кн. 2, с. 136].

А.А. Нарышкин, один из лидеров Совета объединенного дворянства, еще в феврале 1907 г. предупреждал Столыпина, что местная реформа, предусматривающая фактическую замену предводителя дворянства чиновниками-бюрократами, не будет поддержана сословием, подчеркивая, что она базируется на «демократических» принципах. На III съезде уполномоченных дворянских обществ реформа была практически отвергнута. Н.Е. Марков призвал правительство «никаких реформ в земстве не вводить, ибо время для этого неподходящее», так как «вносить такой проект земс- 
кой реформы - это значит сознательно лучшую часть народа бросать в грязь» [22, т. 1, с. 387]. Постоянный Совет объединенного дворянства обратился с предложением к П.А. Столыпину вынести реформу местного управления на обсуждение дворянских и земских уездных и губернских собраний и лишь затем представить ее на суд Думы. Однако П.А. Столыпин категорически не разделял мнение представителей дворянской корпорации.

С помощью внесенного на обсуждение Государственной думы законопроекта о волостном правлении (1908 г.) власть пыталась приобщить население к участию в земской деятельности. Законопроект был направлен на преобразование волостного управления на началах бессословности, однако практически не расширял хозяйственную деятельность волости. Он не отвечал назревшей потребности в децентрализации уездного земского хозяйства, поэтому был раскритикован даже центристскими кругами III Государственной думы, которые выражали мнение либеральных земских деятелей.

IV съезд Совета объединенного дворянства (март 1908 г.) обобщил постановления состоявшихся в 1907 - начале 1908 г. дворянских и земских собраний и резко раскритиковал проект местной реформы. Участники съезда предъявили обвинения правительству П.А. Столыпина. Они негативно оценили предполагаемые меры, прежде всего устранение предводителя дворянства от руководящей роли в уезде, образование всесословного земства в волости и изменения в земском избирательном праве. Не решаясь откровенно заявлять о неприкосновенности сословных привилегий дворянства, участники съезда отмечали вред жестких, радикальных реформ в современных условиях, когда и без того «многое поколеблено» $[22$, т. 1 , с. 565-574, 593-598, 779-888]. С.Ф. Шарапов прямо потребовал от руководителей Постоянного совета «...поставить на вид правительству, что в силу неизвестных мотивов, вероятно вследствие только недавней всеобщей растерянности и общей реформационной горячки, оно выступило с целой массой законопроектов, ломающих местную жизнь» [22, т. 1, с. 579]. Призыв В.И. Гурко не только критиковать проекты реформ, предлагаемые правительством, а разработать основные положения местной реформы, не был услышан. В выступлениях дворянских лидеров рефреном звучала мысль, что П.А. Столыпин желает разрушить «все те общественные единения, которые еще полны жизненности и значения», заменить их искусственно созданными формами. Реформы предлагалось проводить с обязательным участием сословия и под контролем самодержавной власти. В.Н. Ознобишин обобщил мнения членов съезда: «...законопроект этот есть продукт стремления в корне задушить остатки службы по долгу, по обязанности, которую несло дворянство» [22, т. 1, с. 581]. А.Н. Брянчанинов заявил, что, несмотря на свои либеральные взгляды, он разделяет точку зрения консерваторов на этот вопрос и полагает, что «какая угодно опека, хотя бы даже консервативная, будет предпочтительнее опеки людей, чуждых интересам лиц, живущих на местах» [22, т. 1 , с. 586]. Идея о принципиальной разнице между службой уездного предводителя дворянства и службой чиновника по найму, контекстом звучала в выступлениях делегатов съезда. Дворянство заявляло, что реформатор П.А. Столыпин забегает вперед, и выразило надежду на то, что местная реформа никогда не осуществится. Вновь представители сословия вернулись к обсуждению данной проблемы на V съезде объединенного дворянства (1909 г.). В прениях по докладу С.А. Панчулидзева «О реформе местного управления» они вновь и вновь говорили о «громадной опасности» проекта. Дворяне полагали, что невозможно устранение уездных предводителей дворянства от председательства в большинстве уездных комиссий. Обвинения П.А. Столыпина в «ревнивом отношении к власти» Г.А. Шечков обосновывал тем, что по замыслу правительственного проекта предводитель дворянства устранен от руководства в уезде, поскольку он не подотчетен министру внутренних дел [22, т. 2, кн. 1, с. 85-87, 95-97, 104-105, 288-298].

Негативное отношение к бюрократии преобладало в оценках дворянством представителей губернской власти. Разобщенность между властью и обществом на местном уровне, дистанцирование губернатора от местных проблем и конфликты с представителями дворянской корпорации способствовали 
нарастанию отчужденности и обостряли политическую ситуацию в губерниях. В связи с этим дворянство выступило противником правительственного проекта губернской реформы. Н.Е. Марков, хотя и подчеркивал, что «сейчас во главе правительства стоит лицо, которому большинство дворян доверяет, так же как и я, как и весь русский народ», тем не менее предостерегал дворянство, говоря о недопустимости изменений в назначении губернаторов. Он предложил обратиться с ходатайством к Николаю II, в котором просить, «чтобы во всяком случае начальник губернии был бы представителем его Императорского Величества». «Не можем мы... допустить возникновения ситуации, когда все эти представители правительства, начальники губерний» получат телеграмму министра внутренних дел, извещающую, что «отныне Монарха нет, а есть республика», и тут же «переменят направление», - пророчески заявлял он [22, т. 2, кн. 1, с. 203-204]. Депутаты VI съезда объединенного дворянства подчеркивали, что реформа может «умалить власть Самодержца-государя». Дискуссия вылилась в обсуждение возможных негативных последствий перемещения власти от императора к первому министру.

Сама личность П.А. Столыпина воспринималась дворянством неоднозначно. Его обвиняли не только в радикальных левых взглядах, но и в смуте, нестабильности в обществе, революционных потрясениях. Даже когда на II съезде объединенных дворянских обществ граф А.А. Бобринский предложил выразить сочувствие П.А. Столыпину в связи со взрывом дачи на Аптекарском острове, разразилась острая дискуссия. Личность реформатора стала оцениваться в связи с его программой. Призвав «приветствовать П.А. Столыпина как за его мужество и его личные достоинства», В.Н. Снежков отметил необходимость высказать «сочувствие его политической программе». На что князь А.П. Урусов и М.Н. Головин возразили, что выражать одобрение программе П.А. Столыпина преждевременно, так как она еще не рассматривалась на съезде [22, т. 1. с. 157, 198]. В.Л. Кушелев на V съезде объединенного дворянства отмечал, что «мы все более или менее уважаем» премьера Столыпина. Единственный представитель либеральной оппозиции на съезде А.Н. Брянчанинов заявил, что по мере угасания революционного движения менялась оценка реформ, проводимых правительством П.А. Столыпина. «В прошлом году, а тем более 2 года назад (в 1907 г. - Aвm.), - подчеркнул он, - угар реакционного настроения был еще так силен, что никакая критика тех лиц, которые ныне находятся у власти, была бы невозможна». Благодарность по отношению к правительству за спасение «дворянских гнезд» от крестьянских погромов постепенно улетучивалась. На смену ей приходило убеждение, что «одно дело - держать в кулаке нити виселиц, а другое - направить хозяйственную жизнь страны в то русло, которое обеспечивает выход из тупика» [22, т. 2, кн. 1, с. 97, 150].

Консервативное политическое крыло было недовольно самостоятельной политикой П.А. Столыпина. Оно считало, что «фигура премьера сильно заслоняет собой Государя и это вызывает недоумение и соблазн». Реформы, проводимые П.А. Столыпиным, с их точки зрения, могли радикально изменить существующую социально-экономическую систему. Американский исследователь А. Ашер полагает, что обличения Столыпина со стороны реакционеров оказались «губительны для его политической карьеры» [34, p. 2]. К 1911 г. Столыпин остался один без поддержки со стороны как дворянства, так и политической бюрократии. По мере умиротворения страны и упрочения своего личного положения менялось и психологическое состояние П.А. Столыпина. У него постепенно появлялась мысль о своей незаменимости, убежденность в правоте своих действий. В.И. Гурко отмечал, что «власть ударила ему в голову, а окружавшие его льстецы сделали остальное», он «возомнил о себе как о выдающейся исторической личности» $[6$, с. 602-603]. Положение П.А. Столыпина становилось все более трудным, недовольство его действиями выражал и Николай II. 4 марта 1911 г. правые в Государственном совете проголосовали против законопроекта о западном земстве. Столыпин подал в отставку, которая не была принята. Николай II не хотел создавать парламентский прецедент, но политическая карьера Столыпина была закончена. Сам П.А. Столыпин прекрасно понимал, что его независимая 
политика раздражает многих, находящихся в окружении царя. О том, что симпатии царя к Столыпину исчезли, свидетельствует беседа императора с В.Н. Коковцовым, в которой он выразил пожелание, чтобы новый премьер не шел по стопам своего предшественника, который постоянно хотел заслонить собой монарха [33, т. 2, с. 198]. В.Н. Коковцов искренне удивлялся, что всего лишь через месяц после трагической гибели Столыпина о нем уже «говорили тоном полного спокойствия, мало кто уже и вспоминал о нем» [14, кн. 2, c. 7-8]. В статье «Историческая роль Столыпина» писатель и философ В.В. Розанов отмечал, что «Столыпин сыграл огромную роль - просто русского человека и просто нравственного человека, в котором не было ни йоты ни красного, ни белого нигилизма» [25, с. 154].

Результаты. Пытаясь спасти свои экономические и политические привилегии, лишь часть правящей элиты поддержала проведение столыпинских реформ. Аграрная реформа была одним из инструментов, способствовавших ускорению модернизационных процессов и развитию промышленного потенциала в России. Она сняла остроту социальных противоречий в деревне между сельской общиной и дворянами - землевладельцами, но одновременно привела к всплеску протестных настроений против землеустроенных крестьян. Попытки Столыпина вести плодотворную работу с монархически-октябристской Думой не были поддержаны право-консервативными силами. Реорганизация местного управления и самоуправления была провалена благодаря усилиям поместного дворянства. Правые, устраняя П.А. Столыпина от управления государством, возводя стену непонимания и недоверия между императором и последним реформатором Российской империи, сами того не осознавая, подписывали близкий смертельный приговор и себе, и Российской империи. «Менять, ничего не меняя» было уже невозможно. Трагедия последнего реформатора Российской империи П.А. Столпина состояла в том, что он не имел социальной опоры ни среди правящей элиты и дворянства, ни в обществе, что в конечном счете привело к его изоляции и трагической гибели.

\section{СПИСОК ЛИТЕРАТУРЫ}

1. Аврех, А. Я. Столыпин и судьбы реформ в России / А. Я. Аврех. - М. : Политиздат, 1991. - 286 с.

2. Аврех, А. Я. Столыпин и Третья дума / А. Я. Аврех. - М. : Наука, 1968. - 520 с.

3. Анфимов, А. М. П.А. Столыпин и российское крестьянство / А. М. Анфимов. - М. : ИРИ РАН, 2002. $-300 \mathrm{c}$.

4. Баринова, Е. П. Власть и поместное дворянство в России в начале XX века / Е. П. Баринова. Самара : Самарский университет, 2002. - 364 с.

5. Бородин, А. П. Объединенное дворянство и аграрная реформа / А. П. Бородин // Вопросы истории. - 1993. - № 9. - С. 33-44.

6. Гурко, В. И. Черты и силуэты прошлого. Правительство и общественность в царствование Николая II в изображении современника / В. И. Гурко. М. : Новое литературное обозрение, 2000. - 746 с.

7. Дякин, В. С. Был ли шанс у Столыпина / В. С. Дякин // Звезда. - 1990. - № 12. - С. 113-124.

8. Дякин, В. С. Самодержавие, буржуазия и дворянство в 1907-1911 гг. / В. С. Дякин. - Л. : Наука, 1978. - 248 с.

9. Зырянов, П. Н. Столыпин без легенд / П. Н. Зырянов. - М. : Знание, 1991. - 64 с.

10. Зырянов, П. Н. Петр Столыпин. Политический портрет / П. Н. Зырянов. - М. : Высшая школа, 1992. $-160 \mathrm{c}$.

11. Кабытов, П. С. П.А. Столыпин: последний реформатор Российской империи / П. С. Кабытов. М. : РОССПЭН, 2007. - 192 c.

12. Казарезов, В. В. П.А. Столыпин: история и современность / В. В. Казарезов. - Новосибирск : РИД, 1991. $-128 \mathrm{c}$.

13. Кауфман, А. А. Аграрный вопрос в России : Лекции, чит. в Моск. нар. ун-те в 1907 г. : в 2 т. / А. А. Кауфман. - М. : Тип. т-ва И.Д. Сытина, 1908. T. $1 .-170$ c. ; T. $2 .-167$ c.

14. Коковцов, В. Н. Из моего прошлого. Воспоминания 1903-1913 гг. : в 2 кн. / В. Н. Коковцов. М. : Наука, 1992. - Кн. 2. -456, [1] с.

15. Коцонис, Я. Как крестьян делали отсталыми: сельскохозяйственные кооперативы и аграрный вопрос в России, 1861-1914 / Я. Коцонис. - М. : НЛО, 2006. - 320 c.

16. Ленин, В. И. Столыпин и революция / В. И. Ленин // Полн. собр. соч. : в 55 т. - М. : Госполитиздат, 1958-1965. - Т. 20. - С. 324-333.

17. Маслов, П. П. Аграрный вопрос в России : в 2 т. / П. П. Маслов. - М. : Тип. т-ва «Общественная польза», 1908. - Т. 1. - 520 с.; Т. 2. - 135 с.

18. Мацузато, К. Столыпинская реформа и российская агротехнологическая революция / К. Мацузато // Отечественная история. - 1992. - № 6. C. 194-199. 
19. Мэйси, Д. Земельная реформа и политические перемены. Феномен Столыпина / Д. Мейси // Вопросы истории. - 1993. - № 4. - С. 3-18.

20. Наумов, А. Н. Из уцелевших воспоминаний. 1868-1917 / А. Н. Наумов. - Нью-Йорк : Изд. А.К. Наумовой и О.А. Кусевицкой, 1954-1955. Кн. 1. -540 с. ; Кн. 2. -842 с.

21. Островский, И. В. П.А. Столыпин и его время / И. В. Островский. - Новосибирск : Наука, Сиб. отд-ние, 1992. - 144 с.

22. Объединенное дворянство. Съезды уполномоченных губернских дворянских обществ. 19061916 / сост. А. П. Корелин. - М. : РОССПЭН, 2001. Т. 1. 1906-1908. - 926 с. ; Т. 2 : в 2 кн. - Кн. 1. 19091910. -679 с. ; Кн. 2. 1911-1912. -608 с.

23. Ольденбург, С. С. Царствование Николая II / С. С. Ольденбург. - М. : АСТ, 2003.-776 с.

24. Пешехонов, А. В. Программные вопросы / А. В. Пешехонов. - Пг. : Задруга, 1917. - Вып. 12. $-47 \mathrm{c}$

25. Розанов, В. Историческая роль Столыпина / В. Розанов // Наш современник. - 1991. - № 3. C. $152-156$.

26. Столыпин, П. А. Полное собрание речей в Государственной думе и Государственном Совете. 1906-1911. Нам нужна великая Россия / П. А. Столыпин. - М. : Молодая гвардия, 1991.-411 с.

27. Солженицын, А. И. Столыпин и царь. Главы из книги «Красное Колесо» / А. И. Солженицын. Екатеринбург : У-Фактория, 2001.-448 с.

28. Соловьев, Ю. Б. Самодержавие и дворянство в 1902-1907 гг. / Ю. Б. Соловьев. - Л. : Наука, 1981. $-256 \mathrm{c}$.

29. Суханов, Н. Н. К вопросу об эволюции сельского хозяйства. Социальные отношения в крестьянском хозяйстве России / Н. Н. Суханов. - М. : Сотрудничество, 1909. $-414 \mathrm{c}$.

30. Тагирова, Н. Ф. Рынок Поволжья (вторая половина XIX - начало XX вв.) / Н. Ф. Тагирова. - М. : Издат. центр науч. и учеб. программ, $1999 .-309 \mathrm{c}$.

31. Чернов, В. М. Марксизм и аграрный вопрос / В. М. Чернов. - СПб. : ред. журн. «Русское богатство», 1906. $-246 \mathrm{c}$.

32. Шанин, Т. Революция как момент истины. Россия 1905-1907 $\rightarrow$ 1917-1922 гг. / Т. Шанин. - М. : Весь мир, 1997. - 560 с.

33. Шидловский, С. И. Воспоминания. В 2 ч. Ч. 2 / С. И. Шидловский. - Берлин : ТО Кирхнер и KO, 1923. - $212 \mathrm{c}$.

34. Ascher, Abraham. P.A. Stolypin: The Search for Stability in Late Imperial Russia / Abraham Ascher. Stanford, California : Stanford University Press, 2001. $468 \mathrm{p}$.

35. Yaney, George L. The Urge to Mobilize: Agrarian Reform in Russia, 1861-1930 / George
L. Yaney. - Urbana, Chicago, and London: University of Illinois Press, 1982. -599 p.

\section{REFERENCES}

1. Avrekh A.Ya. Stolypin i sudby reform v Rossii [Stolypin and the Fate of Reforms in Russia]. Moscow, Politizdat, 1991. 286 p.

2. Avrekh A.Ya. Stolypin i Tretya Duma [Stolypin and the Third Duma]. Moscow, Nauka Publ., 1968. $520 \mathrm{p}$.

3. Anfimov A.M. P.A. Stolypin i rossiyskoe krestyanstvo [P.A. Stolypin and Russian Peasantry]. Moscow, IRI RAN, 2002. $300 \mathrm{p}$.

4. Barinova E.P. Vlast i pomestnoe dvoryanstvo $v$ Rossii v nachale XX veka [Vlast and Landed Nobility in Russia in the Early $20^{\text {th }}$ Century]. Samara, Samarskiy universitet, 2002. 364 p.

5. Borodin A.P. Obedinennoe dvoryanstvo i agrarnaya reforma [Joint Nobility and Agrarian Reform]. Voprosy istorii, 1993. no. 9, pp. 33-44.

6. Gurko V.I. Cherty i siluety proshlogo. Pravitelstvo $i$ obshchestvennost $v$ tsarstvovanie Nikolaya II v izobrazhenii sovremennika [Features and Silhouettes of the Past: The Government and the Public in the Reign of Nicholas II in the Image of a Contemporary]. Moscow, Novoe literaturnoe obozrenie, 2000. 746 p.

7. Dyakin V.S. Byl li shans u Stolypina? [Did Stolypin Had a Chance?]. Zvezda Publ., 1990, no. 12, pp. 113-124.

8. Dyakin V.S. Samoderzhavie, burzhuaziya $i$ dvoryanstvo v 1907-1911 gg. [Autocracy, the Bourgeoisie and the Nobility in 1907-1911]. Leningrad, Nauka Publ., 1978. 248 p.

9. Zyryanov P.N. Stolypin bez legend [Stolypin Without Legends]. Moscow, Znanie Publ., 1991. 64 p.

10. Zyryanov P.N. Petr Stolypin. Politicheskiy portret [Petr Stolypin. Political Portrait]. Moscow, Vysshaya shkola Publ., 1992. 160 p.

11. Kabytov P.S. P.A. Stolypin: posledniy reformator Rossiyskoy imperii [Stolypin: Last Reformer of the Russian Empire]. Moscow, ROSSPEN, 2007. 192 p.

12. Kazarezov V.V. P.A. Stolypin: istoriya $i$ sovremennost [P.A. Stolypin: History and Modernity]. Novosibirsk, RID, 1991. 128 p.

13. Kaufman A.A. Agrarnyy vopros v Rossii. Lektsii, chit. v Mosk. nar. un-te v 1907 g. [The Agrarian Issue in Russia. Lectures, Read in Moscow City People's University in 1907]. Moscow, Tipografiya tovarishchestva I.D. Sytina, 1908, vol. 1. 170 p.; vol. 2, $167 \mathrm{p}$.

14. Kokovtsov V.N. Iz moego proshlogo. Vospominaniya 1903-1913 gg. [From My Past. 
Memoirs of 1903-1913]. Moscow, Nauka Publ., 1992. Book 2. 456, [1] p.

15. Kotsonis Ya. Kak krestyan delali otstalymi: selskokhozyaystvennye kooperativy i agrarnyy vopros v Rossii, 1861-1914 [Making Peasants Backward: Agricultural Cooperatives and the Agrarian Issue in Russia, 1861-1914]. Moscow, NLO Publ., 2006. 320 p.

16. Lenin V.I. Stolypin i revolyutsiya [Stolypin and the Revolution]. Poln. sobr. soch. : v 55 t. [Complete Works in 55 Volumes]. Moscow, Gospolitizdat, 19581965, vol. 20, pp. 324-333.

17. Maslov P.P. Agrarnyy vopros v Rossii. $V 2 t$. [The Agrarian Issue in Russia. In 2 Vols]. Moscow, Tipografiya tovarishchestva «Obshchestvennaya polza», 1908., vol. 1.520 p; vol. 2. 135 p.

18. Matsuzato K. Stolypinskaya reforma i rossiyskaya agrotekhnologicheskaya revolyutsiya [Stolypin Reform and the Russian Agrotechnological Revolution]. Otechestvennaya istoriya [Russian History], 1992, no 6, pp. 194-199.

19. Meysi D. Zemelnaya reforma i politicheskie peremeny. Fenomen Stolypina [Land Reform and Political Changes. Stolypin's Phenomenon].Voprosy istorii, 1993, no. 4, pp. 3-18.

20. Naumov A.N. Iz utselevshikh vospominaniy. 1868-1917 [Surviving Memoirs. 1868-1917]. New York, Izd-vo A.K. Naumovoy i O.A. Kusevitskoy, 1954 1955, book 1. 540 p.; book 2. 842 p.

21. Ostrovskiy I.V. P.A. Stolypin i ego vremya [P.A. Stolypin and His Time]. Novosibirsk, Nauka Publ., Sibirskoe otdelenie, 1992. $144 \mathrm{p}$.

22. Korelin A.P., ed. Obedinennoe dvoryanstvo. Sezdy upolnomochennykh gubernskikh dvoryanskikh obshchestv. 1906-1916 [Joint Nobility. Congresses of Authorized Provincial Noble Societies. 1906-1916]. Moscow, ROSSPEN, 2001, vol. 1, 1906-1908. 926 p.; vol. 2 in 2 books, book 1, 1909-1910. 679 p.; book 2 , 1911-1912. $608 \mathrm{p}$.

23. Oldenburg S.S. Tsarstvovanie Nikolaya II [Reign of Nicholas II]. Moscow, AST Publ., 2003. 776 p.

24. Peshekhonov A.V. Programmnye voprosy [Program Questions]. Petrograd, Zadruga Publ., 1917, iss. $1-2.47 \mathrm{p}$.
25. Rozanov V. Istoricheskaya rol Stolypina [Historical Role of Stolypin]. Nash sovremennik,1991. no. 3, pp. 152-156.

26. Stolypin P.A. Polnoe sobranie rechey $v$ Gosudarstvennoy dume $i$ Gosudarstvennom Sovete. 1906-1911. Nam nuzhna velikaya Rossiya [Complete Collection of Speeches in the State Duma and the State Council. 1906-1911. We Need a Great Russia]. Moscow, Molodaya gvardiya Publ., $1991.411 \mathrm{p}$.

27. Solzhenitsyn A.I. Stolypin i tsar. Glavy iz knigi "Krasnoe Koleso" [Stolypin and Tsar. Chapters from "Red Wheel” Book]. Yekaterinburg, U-Faktoriya Publ., 2001. 448 p.

28. Solovyev Yu.B. Samoderzhavie i dvoryanstvo v 1902-1907 gg. [Autocracy and the Nobility in 19021907]. Leningrad, Nauka Publ., 1981. 256 p.

29. Sukhanov N.N. K voprosu ob evolyutsii selskogo khozyaystva. Sotsialnye otnosheniya $v$ krestyanskom khozyaystve Rossii [On the Issue of the Evolution of Agriculture. Social Relations in the Peasant Economy of Russia]. Moscow, Sotrudnichestvo Publ., 1909. 414 p.

30. Tagirova N.F. Rynok Povolzhya (vtoraya polovina XIX - nachalo $X X v v$.) [The Market of the Volga Region (Late $19^{\text {th }}-$ Early $20^{\text {th }}$ c.) ]. Moscow, Izdatelskiy tsentr nauchnykh i uchebnykh programm, 1999. 309 p.

31. Chernov V.M. Marksizm i agrarnyy vopros [Marxism and the Agrarian Issue]. Saint Petersburg, Redaktsiya zhurnala «Russkoe bogatstvo», 1906. 246 p.

32. Shanin T. Revolyutsiya kak moment istiny. Rossiya 1905-1907 $\rightarrow$ 1917-1922 gg [Revolution as a Moment of Truth. Russia 1905-1907 $\rightarrow$ 19171922]. Moscow, Ves mir Publ., 1997. 560 p.

33. Shidlovskiy S.I. Vospominaniya. V2 ch. Ch. 2 [Memoirs. In 2 parts. Part 2]. Berlin, TO Kirkhner i KO, 1923. 212 p.

34. Ascher A. P.A. Stolypin: The Search for Stability in Late Imperial Russia. Stanford, California, Stanford University Press, 2001. 468 p.

35. Yaney G.L. The Urge to Mobilize: Agrarian Reform in Russia, 1861-1930. Urbana, Chicago, and London, University of Illinois Press, 1982. 599 p.

\section{Information about the Authors}

Petr S. Kabytov, Doctor of Sciences (History), Professor, Honored Science Worker of the Russian Federation, Head of the Department of the Russian History, Samara National Research University, Akademika Pavlova St., 1, 443011 Samara, Russian Federation, don.kabytov2012@yandex.ru, https:// orcid.org/0000-0002-2359-2155

Ekaterina P. Barinova, Doctor of Sciences (History), Professor, Department of Institutional Economy and Economic History, Samara State Economic University, Sovetskoy Armii St., 141, 443090 Samara, Russian Federation, rfnz25@yandex.ru, https://orcid.org/0000-0002-2514-9421 


\section{Информация об авторах}

Петр Серафимович Кабытов, доктор исторических наук, профессор, заслуженный деятель науки РФ, заведующий кафедрой российской истории, Самарский национальный исследовательский университет им. акад. С.П. Королева, ул. Академика Павлова, 1, 443011 г. Самара, Российская Федерация, don.kabytov2012@yandex.ru, https://orcid.org/0000-0002-2359-2155

Екатерина Петровна Баринова, доктор исторических наук, профессор кафедры институциональной экономики и экономической истории, Самарский государственный экономический университет, ул. Советской Армии, 141, 443090 г. Самара, Российская Федерация, rfnz25@yandex.ru, https://orcid.org/0000-0002-2514-9421 